\title{
Analysis of Minimum temperature spatially and temporally over Iraq During the period 1980-2015
}

\author{
Yassen K. Al-Timimi, Aws A. Al-Khudhairy \\ Department of Atmospheric Science, College of Science, University of Al-Mustansiriyah, Iraq.
}

\begin{abstract}
Monthly Minimum surface air temperature at 23 stations in Iraq were analyzed for temporal trends and spatial variation during 1980-2015.seasonal and annual temperature was analyzed using Mann-Kendall test to detect the significant trend .The results of temporal analysis showed that during winter , spring, summer and Autumn have a positive trend in all the parts of Iraq. A tendency has also been observed towards warmer years, with significantly warmer summer and spring periods and slightly warmer autumn and winter, the highest increase is $(3.9){ }^{\circ} \mathrm{C}$ in Baghdad during the summer. The results of spatial analyze using the ArcGIS showed that the seasonal temperature can be divided into two or three distinct areas with high temperature in the south and decreasing towards north, where the trend of spatial temperature were decreasing from south to the north in all the four seasons.
\end{abstract}

Key words: Trend, Temperature, Mann-Kendall, ArcGIS, Iraq.

\section{Introduction}

Temperature is one of the most influential elements of Meteorological and Climatological Components, cause its directly affected in our lives. The global average surface temperature has increased in the $20^{\text {th }}$ century by about $\left(0.6^{\circ} \mathrm{C}\right)$. Recent studies reveal a significant worldwide warming and a general increase in frequencies and persistence of high temperatures, one of the major concerns with that potential change in climate is the increase in extreme events will occur. Generally the global surface temperature has been increasing over the past 100 years by presumably due to the greenhouse effect, as a result of increasing concentrations of carbon dioxide and other greenhouse gases into the atmosphere. This warming trend has exhibited considerable temporal and spatial Variabilities [1]. Global mean air surface temperature has risen in the Twentieth century, and it's expected to rise by $\left(1.8-4.0^{\circ} \mathrm{C}\right)$ in the twenty first century [2]. Because global and regional effects of global warming become apparent that cause the studies on monitoring global and regional temperature change

Received: 27-09-2017; Accepted 12-10-2017; Published Online 16-10-2017

${ }^{*}$ Corresponding Author

Yassen K. Al-Timimi, Aws A. Al-Khudhairy, Department of Atmospheric Science, College of Science, University of Al-Mustansiriyah, Iraq. have sharply increased in the last few decades. Global average surface air temperature has increase by $\left(0.13^{\circ} \mathrm{C}\right)$ to $\left(0.03^{\circ} \mathrm{C}\right)$ per decade over the last 50 years according to (IPCC) Which is one of the most important association providing data on the global warming changes and it's brief to intergovernmental panel on climate change and it's established back in 1988 [3]. Many regional studies have also indicated a positive trend in temperature although the changes slightly vary from one region to another indicated, the annual mean temperature has increased between $\left(0.5^{\circ} \mathrm{C}\right)$ and $\left(1.58^{\circ} \mathrm{C}\right)$ in the south parts of Canada over the 20 th century. With an intense warming trend of $\left(+0.08^{\circ} \mathrm{C}+0.03^{\circ} \mathrm{C}\right)$ per decade over Europe, Where Europe has the highest increase $\left(0.43^{\circ} \mathrm{C}\right)$ over the last 30 Years [4]. The analysis of temperature all over the world has shown that the increase is not only in mean annual but also in seasonal, monthly, maximum and minimum temperature [5]. Worldwide analysis of air temperature changes and the studies shown that temperature has increased in both Hemispheres. But warming was more dominant in the northern hemisphere in the last 50 years [6]. Many regional studies have also indicates a positive trend in temperature although the changes slightly vary from one region to another 17$\rceil.$ Mediterranean is the most affected area in the world from global warming, these intensified 
increased in temperature may cause potential evaporation, water Deficit and forest fire risk [8]. This study aimed to examine the spatial and temporal temperature trends in annual and seasonal mean temperatures in Iraq for 35 years time period (1980-2015) by using Mann-Kendall non-parametric test and Sen's method.

\section{Study Area and Data}

The study area is represented by Iraq, where geographically Iraq is located in the semi-tropical latitude in the Northern Hemisphere between latitudes $\left(29.5^{\circ}-37.5^{\circ} \mathrm{N}\right)$ north the equator, and between longitudes $\left(38.45^{\circ}-48.45^{\circ} \mathrm{E}\right)$ east of Greenwich line. Also, Iraq lies in the south west of Asian continent in the northern part of the Arab homeland, the north border is with turkey, Syria, Jordan from the west, Kuwait and Kingdom Saudi Arabia from south and Iran from the east. And this location determines the closeness or the distance of Iraq from water bodies which have clear impact in the climate and thermal properties of Iraq, where the Mediterranean Sea and the Arabian Gulf are the most influential water bodies in Iraq [9].

In this study a historical records of monthly minimum temperature were acquired from the Iraqi Meteorological Organization and Seismology (IMOS) for thirty five years of the period (1980-2015). The long term data were collected from 23 ground weather stations located at different regions of the country. As shown in Table (1) and Figure (1).

Table 1. Meteorological stations that used in the study

\begin{tabular}{|c|c|c|c|c|}
\hline Station & $\begin{array}{l}\text { Station } \\
\text { Number }\end{array}$ & $\begin{array}{c}\text { Longitude } \\
\text { (Degree) }\end{array}$ & $\begin{array}{l}\text { Latitude } \\
\text { (Degree) }\end{array}$ & $\begin{array}{c}\text { Elevation } \\
\text { (Meter) }\end{array}$ \\
\hline Amara & 680 & $47.17^{\circ}$ & $31.83^{\circ}$ & $9.5 \mathrm{~m}$ \\
\hline Baghdad & 650 & $44.4^{\circ}$ & $33.3^{\circ}$ & $31.7 \mathrm{~m}$ \\
\hline Biji & 631 & $43.53^{\circ}$ & $34.9^{\circ}$ & $115.5 \mathrm{~m}$ \\
\hline Basrah & 689 & $47.78^{\circ}$ & $30.52^{\circ}$ & $2 \mathrm{~m}$ \\
\hline Diwaniya & 672 & $44.95^{\circ}$ & $31.95^{\circ}$ & $20 \mathrm{~m}$ \\
\hline Haditha & 634 & $42.35^{\circ}$ & $34.13^{\circ}$ & $108 \mathrm{~m}$ \\
\hline Hella & 657 & $44.45^{\circ}$ & $32.45^{\circ}$ & $27 \mathrm{~m}$ \\
\hline Kerbela & 626 & $44.05^{\circ}$ & $32.57^{\circ}$ & $29 \mathrm{~m}$ \\
\hline Khanqin & 637 & $45.38^{\circ}$ & $34.35^{\circ}$ & $202 \mathrm{~m}$ \\
\hline Kirkuk & 621 & $44.35^{\circ}$ & $35.47^{\circ}$ & $331 \mathrm{~m}$ \\
\hline Kut & 665 & $45.75^{\circ}$ & $32.49^{\circ}$ & $17 \mathrm{~m}$ \\
\hline Mosul & 608 & $43.15^{\circ}$ & $36.31^{\circ}$ & $223 \mathrm{~m}$ \\
\hline Najaf & 670 & $44.32^{\circ}$ & $31.95^{\circ}$ & $53 \mathrm{~m}$ \\
\hline Nasiriya & 676 & $46.23^{\circ}$ & $31.02^{\circ}$ & $5 \mathrm{~m}$ \\
\hline Rabiah & 602 & $42.1^{\circ}$ & $36.37^{\circ}$ & $382 \mathrm{~m}$ \\
\hline Ramadi & 645 & $43.32^{\circ}$ & $33.83^{\circ}$ & $48 \mathrm{~m}$ \\
\hline Rutba & 642 & $40.28^{\circ}$ & $33.03^{\circ}$ & $630.1 \mathrm{~m}$ \\
\hline Samawa & 674 & $45.27^{\circ}$ & $31.27^{\circ}$ & $11.4 \mathrm{~m}$ \\
\hline Sinjar & 604 & $41.83^{\circ}$ & $36.32^{\circ}$ & $583 \mathrm{~m}$ \\
\hline Sulaymaniya & 623 & $45.45^{\circ}$ & $35.53^{\circ}$ & $843 \mathrm{~m}$ \\
\hline Teleafer & 603 & $42.48^{\circ}$ & $36.37^{\circ}$ & $373 \mathrm{~m}$ \\
\hline Arbil & 616 & $44^{\circ}$ & $36.15^{\circ}$ & $420 \mathrm{~m}$ \\
\hline Salahaddin & 611 & $44.2^{\circ}$ & $36.38^{\circ}$ & $1075 \mathrm{~m}$ \\
\hline
\end{tabular}

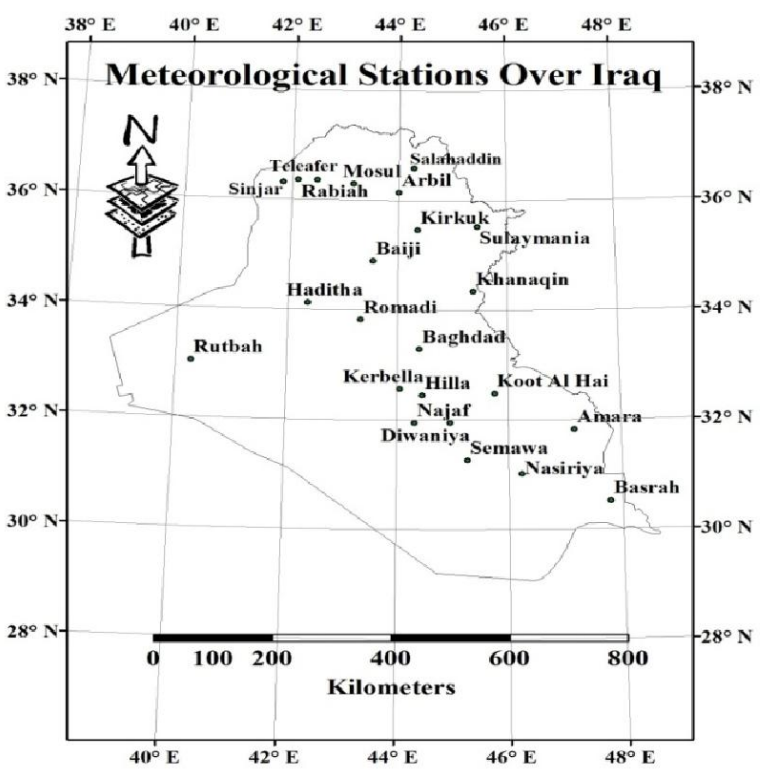

Fig. 1. Meteorological stations in Iraq

\section{Mann-Kendall Test (MK)}

Simple linear regression analysis could give us a primary indication of existence of trend in times series data, whereas another method, such as the non-parametric Mann-Kendall (MK) test, which usually used in hydrologic data analysis, can used to detect trends that are monotonic but not necessarily linear. The MK test does need the assumption of normality, and only indicates the direction but not the magnitude of significant trends [10]. This test is usable in the situations where values xi of a time series may subjected to

$$
x_{i}=f\left(t_{i}\right)+\varepsilon_{i},
$$

The $f(t)$ is continuous monotonic growing or diminishing function with time, while ei presumed to came from same division with zero mean. Thus we can assume that the difference in the division is constant with time.

For testing the null hypothesis when there is no trend for example the monitoring xi are randomly arrange with time, with the substitution hypothesis whereas a rising or declining monotonic trend. For computation of this statistical test MAKESENS exploits both, so we called S statistics and the normal approximation Z statistics in GILBERT [11]. For time series with less than 10 data points the $\mathrm{S}$ test is used, and for time series with 10 or more data points the normal approximation is used. 
Trends were detected in the time series by means of Mann-Kendall test. The Mann-Kendall method has been suggested by the world meteorological organization to assess the trend in environment data time series.

The Mann-Kendall test statistic $\mathrm{S}$ is given by:

$$
S=\sum_{k=1}^{n-1} \sum_{j=k+1}^{n} \operatorname{sgn}\left(x_{j}-x_{k}\right) \text {, }
$$

$\mathrm{x}_{\mathrm{j}}$ and $x_{k}$ represents the annual values in years $j$ and $k, j>k$, respectively, and

$$
\operatorname{sgn}\left(x_{j}-x_{k}\right)= \begin{cases}1 & \text { if } x_{j}-x_{k}>0 \\ 0 & \text { if } x_{j}-x_{k}=0 \\ -1 & \text { if } x_{j}-x_{k}<0\end{cases}
$$

When $n$ is 9 or lower, the absolute value of $\mathrm{S}$ is match straight to the theoretical distribution of $\mathrm{S}$ obtained by Mann-Kendall [11].

The $\mathrm{Z}$ statistics used When the number of Values ten or further. When $\mathrm{n}$ is at minimum 10 thereafter normal approximation test is applied. Although whether there are various tied values for example a similar values in the time series. This may decrease veracity of the normal distribution when the number of values near ten. The contrast of $\mathrm{S}$ calculated by the next equation with consideration that ties would be display as:

$$
\operatorname{VAR}(S)=\frac{1}{18}\left[n(n-1)(2 n+5)-\sum_{p=1}^{q} t_{p}\left(t_{p}-1\right)\left(2 t_{p}+5\right)\right]
$$

Where

$q$ the number of tied groups.

$t_{p}$ the number of data values on the $p^{\text {th }}$ group.

The values of $S$ and $\operatorname{VAR}(S)$ are applied for calculating the $\mathrm{Z}$ test as fallows

$$
Z= \begin{cases}\frac{S-1}{\sqrt{\operatorname{VAR(S)}}} & \text { if } S>0 \\ 0 & \text { if } S=0 \\ \frac{S+1}{\sqrt{\operatorname{VAR(S)}}} & \text { if } S<0\end{cases}
$$

The existence of a statistically significant trend is estimated by using the $Z$ value. A positive (negative) value of $\mathrm{Z}$ indicates an upward (downward) trend [11].

\section{Results}

\section{Temporal Analysis}

The statically significant levels, high (0.01), medium (0.05) and low (0.1) were used in this study. The estimate for magnitude of slope (Q) was computed for significant trends in $\left({ }^{\circ} \mathrm{C} / \mathrm{Year}\right)$. Mann-Kendall test was used to identify the pattern for the analysis of seasonal and annual minimum temperature. Figures 2-5 shows the trends of temperature in the four standard stations it can be seen that there is a slight increase during winter season. In spring season the results reveal an increase in all the trends. While in summer, the trends of minimum temperature shows the most increasing trends between the seasons. Autumn season is characterized by increasing trends in mean temperature with a slight increase or almost the same as in spring season.
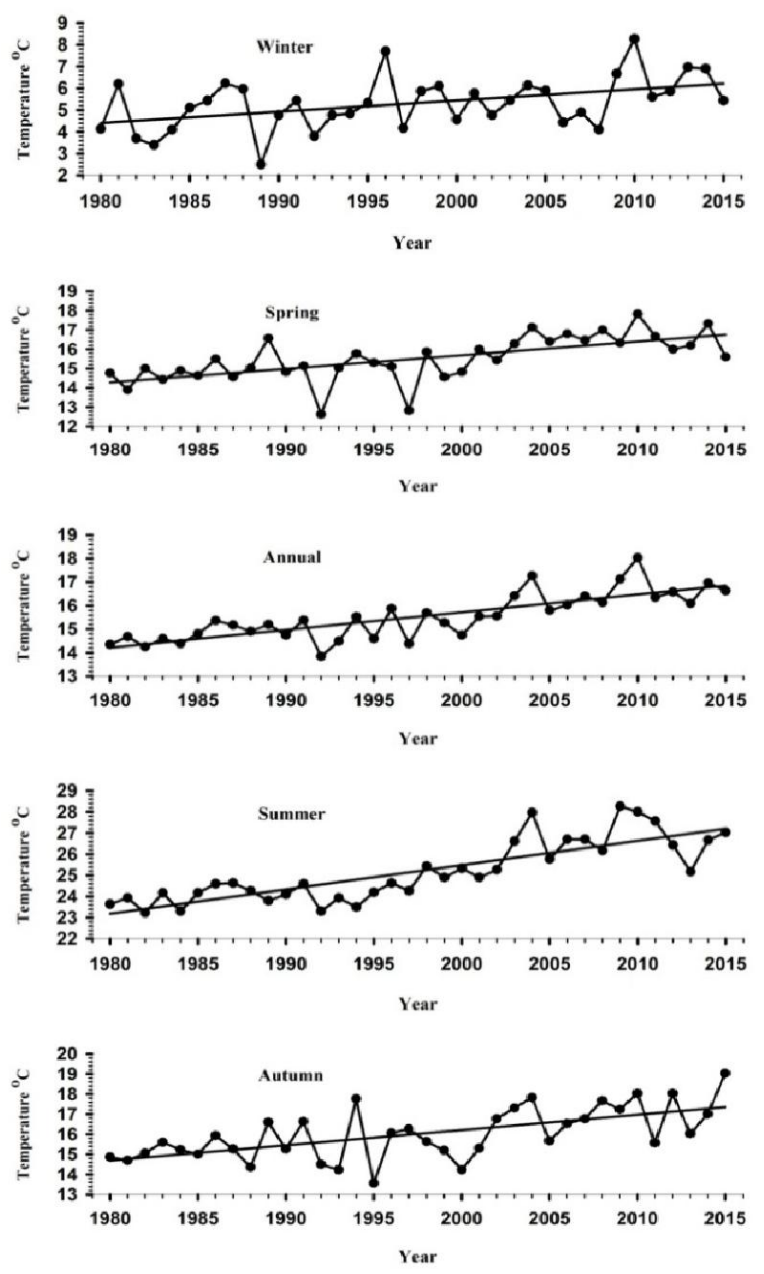

Fig. 2. Seasonally and annually Mean Minimum Temperature at Baghdad Station 
Analysis of Minimum temperature spatially and temporally
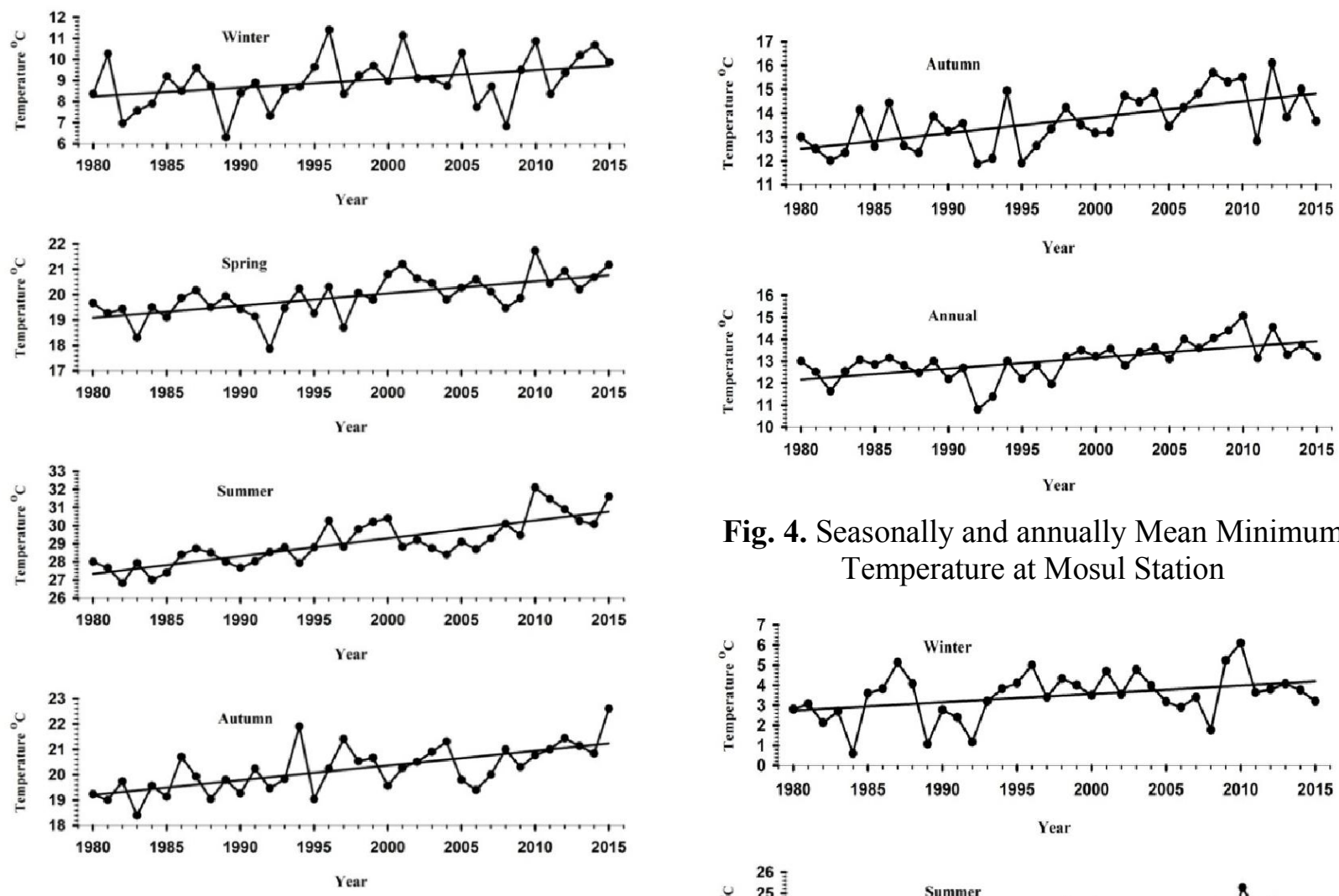

Fig. 4. Seasonally and annually Mean Minimum Temperature at Mosul Station
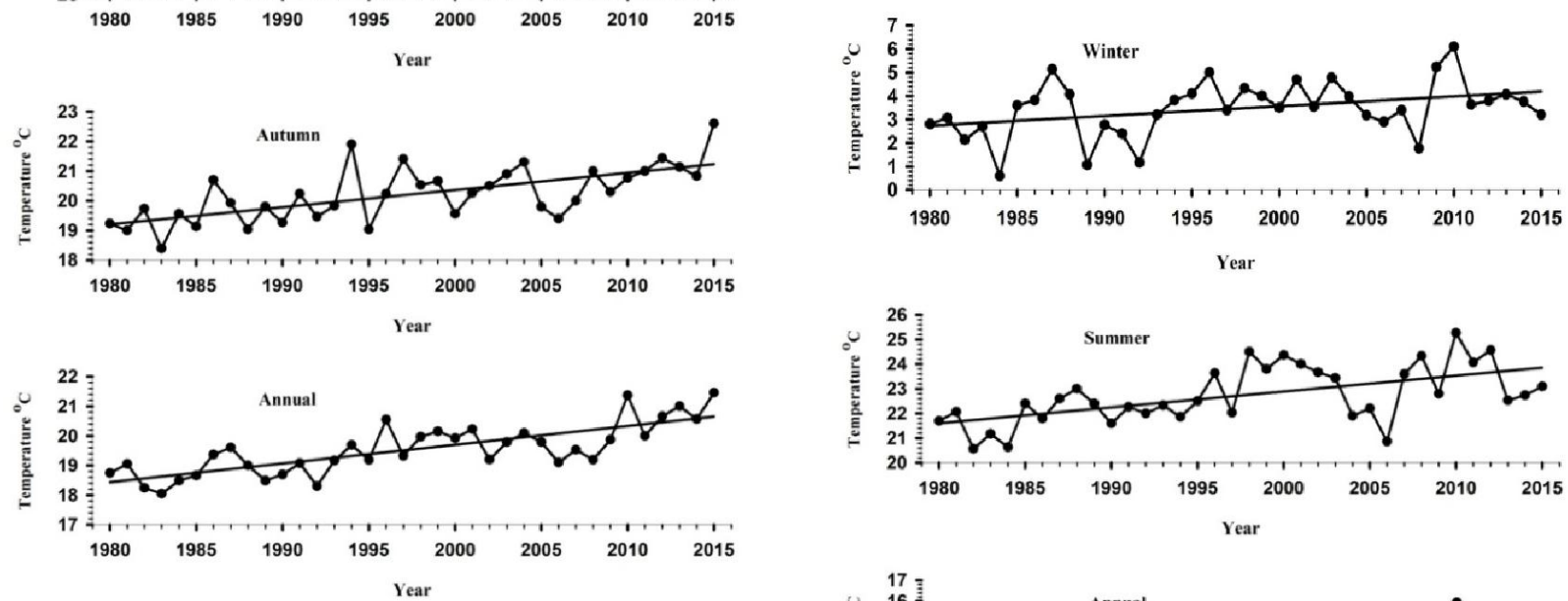

Fig. 3. Seasonally and annually Mean Minimum Temperature at Basrah Station
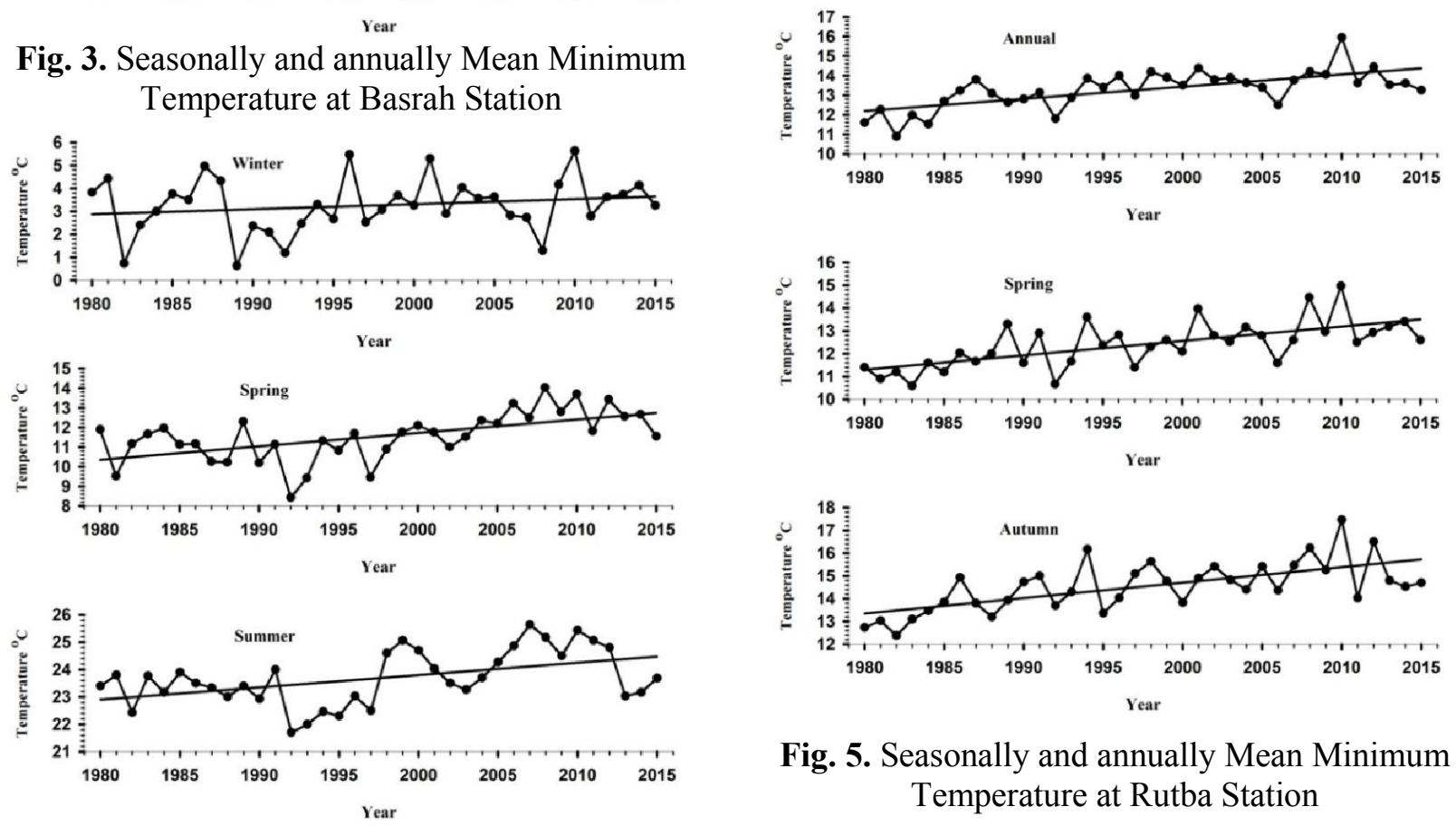

Fig. 5. Seasonally and annually Mean Minimum Temperature at Rutba Station 
From the Table 2, The results of annual analysis shows the highest increase in $\mathrm{Q}\left({ }^{\circ} \mathrm{C} /\right.$ Year $)$ annually was (0.07) noticed in Baghdad station, and the lowest increase was (0.05) noticed in Mosul station.
Seasonally the highest increase in Q $\left({ }^{\circ} \mathrm{C} /\right.$ Year $)$ (0.11) noticed In Summer season at Baghdad station, and the lowest was (0.02) Noticed in winter Season at Mosul station.

Table 2. Mann-Kendall Results annually and seasonally For $T_{\text {min }}$

\begin{tabular}{ccccccccc}
\hline \multirow{2}{*}{ Season } & \multicolumn{2}{c}{ Baghdad } & \multicolumn{2}{c}{ Basrah } & \multicolumn{2}{c}{ Mosul } & \multicolumn{2}{c}{ Rutba } \\
\cline { 2 - 8 } & $\mathbf{Z}$ & $\begin{array}{c}\mathbf{Q} \\
\left({ }^{\circ} \mathbf{C} / \text { Year }\right)\end{array}$ & $\mathbf{Z}$ & $\begin{array}{c}\mathbf{Q} \\
\left({ }^{\circ} \mathbf{C} / \text { Year }\right)\end{array}$ & $\mathbf{Z}$ & $\begin{array}{c}\mathbf{Q} \\
\left({ }^{\circ} \mathbf{C} / \text { Year }\right)\end{array}$ & $\mathbf{Z}$ & $\begin{array}{c}\mathbf{Q} \\
\left({ }^{\circ} \mathbf{C} / \text { Year }\right)\end{array}$ \\
\hline Winter & 2.54 & 0.05 & 2.40 & 0.05 & 1.16 & 0.02 & 2.29 & 0.04 \\
Spring & 4.34 & 0.07 & 4.05 & 0.04 & 3.68 & 0.07 & 4.30 & 0.06 \\
Summer & 5.73 & 0.11 & 5.68 & 0.10 & 2.47 & 0.05 & 3.68 & 0.06 \\
Autumn & 3.93 & 0.08 & 4.25 & 0.06 & 3.70 & 0.07 & 3.98 & 0.07 \\
Annual & 5.51 & 0.07 & 5.05 & 0.06 & 4.33 & 0.05 & 4.11 & 0.06 \\
\hline
\end{tabular}

Spatial Analysis

Seasonal minimum temperature $\left(\mathrm{T}_{\min }\right)$ averaged over Iraq during the period 1980-2015 is displayed in Figure 6. The results reveal that the minimum temperature in the south part of Iraq is higher than the other parts of the country. Generally the temperature distribution of minimum temperature $\mathrm{T}_{\mathrm{Min}}$ in Iraq can be divided into two distinct regions. In winter the temperature distribution over Iraq can be divided into two distinct areas, the north and the west regions was below $5{ }^{\circ} \mathrm{C}$ which cover about $42 \%$, while the other $58 \%$ of the studied area in the center and the east parts down to the southern parts of the country witness temperatures between 5- $10^{\circ} \mathrm{C}$ as shown in Figure (6a) and table (3). The lowest minimum temperature $\mathrm{T}_{\mathrm{Min}}$ in winter was $1.7^{\circ} \mathrm{C}$ and the highest value $8.9^{\circ} \mathrm{C}$. In summer season, generally the temperatures increased all over the country, the lowest temperature observed in the west and the north parts of the country with temperatures between $20-25^{\circ} \mathrm{C}$, While the other regions of the country that occupies about $77 \%$ of the studied area in the southern regions and the center of the country experiments temperature between $25-30^{\circ} \mathrm{C}$ as shown in Figure (6b) and table (3). The lowest minimum temperature $\mathrm{T}_{\mathrm{Min}}$ in summer season was $23.0^{\circ} \mathrm{C}$ and the highest value $28.9^{\circ} \mathrm{C}$. While in spring, the highest minimum temperature observed was in the southern and central parts of the country with temperatures $15-20^{\circ} \mathrm{C}$ which consists about $54 \%$ of the country, while the other $46 \%$ of the studied area in the north and west parts were with temperature below $15^{\circ} \mathrm{C}$ as shown in Figure (6c) and table (3). The lowest minimum temperature $\mathrm{T}_{\text {Min }}$ in spring season was $10.4^{\circ} \mathrm{C}$ and the highest value $19.3^{\circ} \mathrm{C}$. During autumn, the lowest minimum temperature was observed in the northern and the western parts of the country which occupies about $10 \%$ of the studied area with temperature between $10-15^{\circ} \mathrm{C}$, the rest regions which covers the other $90 \%$ of the country from the center up to the north and east parts to the southern parts of the country are with temperatures above $15^{\circ} \mathrm{C}$ as shown in Figure (6d) and table (3).The lowest minimum temperature $\mathrm{T}_{\text {Min }}$ in autumn season was $12.6^{\circ} \mathrm{C}$ and the highest value $19.3^{\circ} \mathrm{C}$.

From the figure (7) and table (4), annual minimum temperature $\left(\mathrm{T}_{\min }\right)$ the temperature decrease almost all over the country, and the temperature distribution over Iraq can be divided into two distinct areas. It can be noticed that the lowest minimum temperatures are in the north and the western regions of the country with temperature below $15^{\circ} \mathrm{C}$ which cover about $31 \%$ of the country, While the other $69 \%$ of the country in the eastern region and the center of the country to the southern region witness temperatures between $15-20^{\circ} \mathrm{C}$. The lowest minimum temperature $\mathrm{T}_{\text {Min }}$ annually was $10.7^{\circ} \mathrm{C}$ and the highest value $19.5^{\circ} \mathrm{C}$. 
(a) Winter

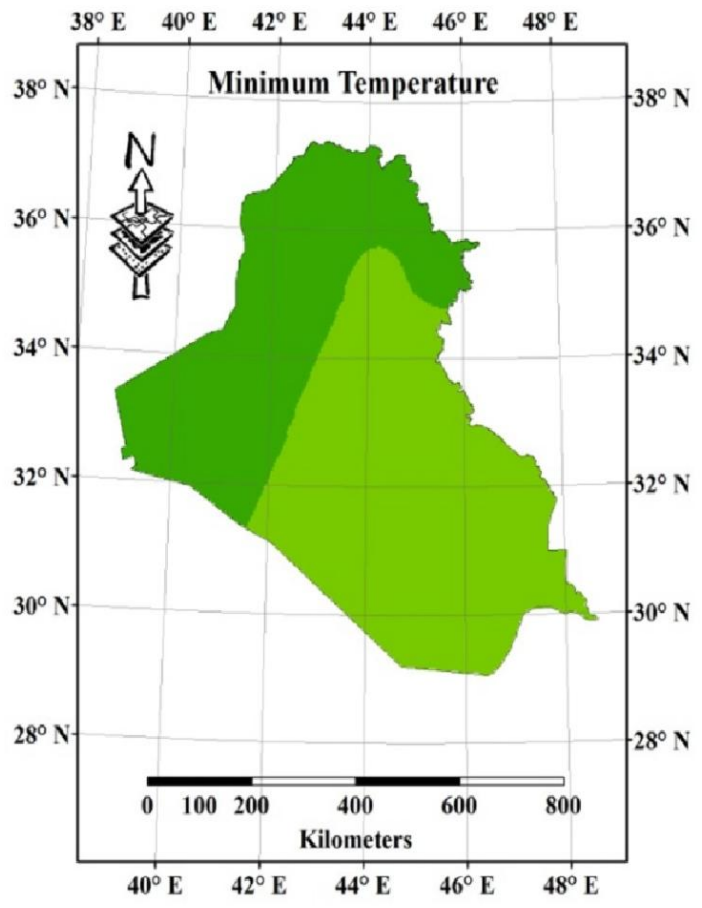

(c) Spring

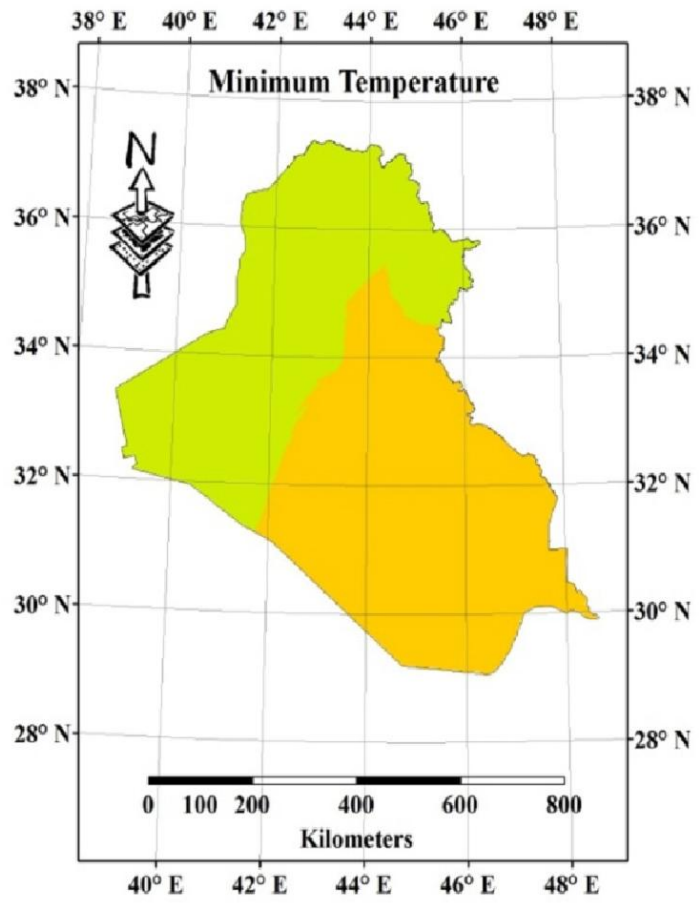

(b) Summer

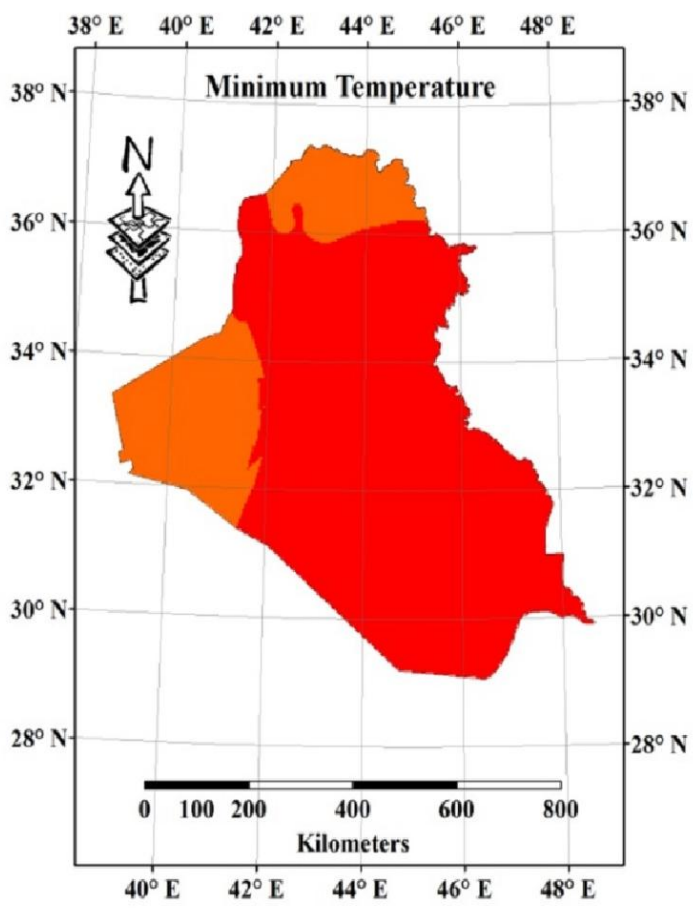

(d) Autumn

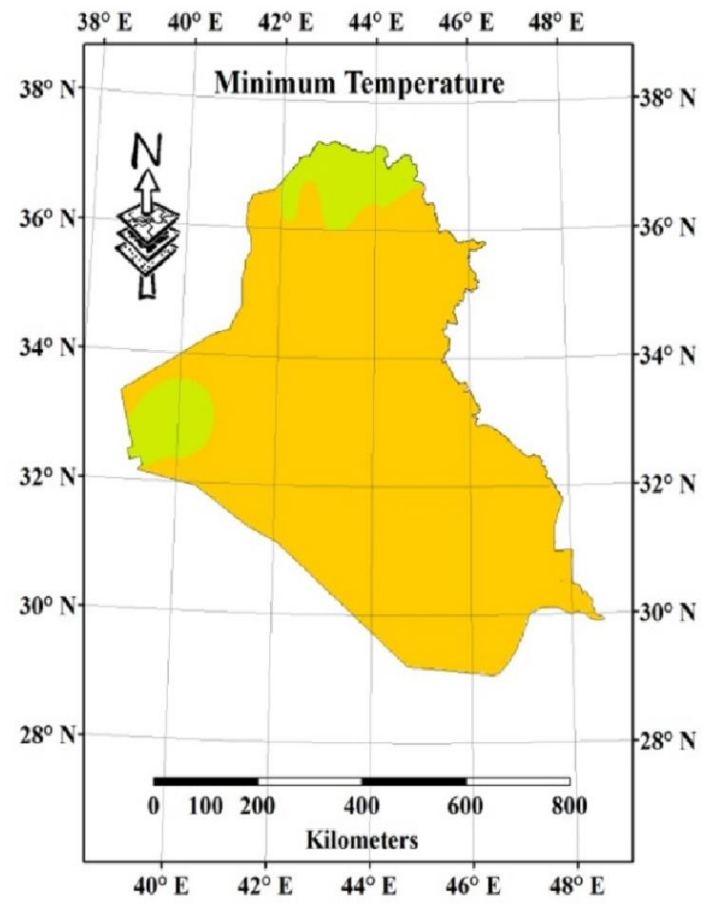

Fig. 6. Spatial Distribution of Seasonal Minimum Temperature $\left(\mathrm{T}_{\mathrm{Min}}\right)$ in $\left({ }^{\circ} \mathrm{C}\right)$ over Iraq for the period 1980-2015 By Kriging Technique in ArcGis 
Yassen K. Al-Timimi, Aws A. Al-Khudhairy (2017)

Table 3. Seasonal $\mathrm{T}_{\min }$ over Iraq for the period 1980-2015

\begin{tabular}{|c|c|c|c|}
\hline \multicolumn{2}{|c|}{ Winter Minimum Temperature ( $\mathbf{T}_{\text {Min }}$ ) } \\
\hline Classes Color & Class Category & Count & Frequency Percent \\
\hline & 1 & 15961 & $41.87 \%$ \\
\hline & 2 & 22156 & $58.13 \%$ \\
\hline & Sum $=38117$ & $100 \%$ \\
\hline Lowest $\mathrm{T}_{\text {Min }}$ in Winter is $1.7^{\circ} \mathrm{C}$ & \\
\hline Highest $\mathrm{T}_{\text {Min }}$ in Winter is $8.9^{\circ} \mathrm{C}$ & \\
\hline
\end{tabular}

\begin{tabular}{|c|c|c|c|}
\hline \multicolumn{4}{|c|}{ Summer Minimum Temperature $\left(\mathbf{T}_{\mathrm{Min}}\right)$} \\
\hline \multirow[t]{4}{*}{ Classes Color } & Class Category & Count & Frequency Percent \\
\hline & 5 & 8861 & $23.25 \%$ \\
\hline & 6 & 29256 & $76.75 \%$ \\
\hline & & Sum $=38117$ & $100 \%$ \\
\hline \multicolumn{4}{|c|}{ Lowest $\mathrm{T}_{\mathrm{Min}}$ in Summer is $23.0^{\circ} \mathrm{C}$} \\
\hline \multicolumn{4}{|c|}{ Highest $\mathrm{T}_{\mathrm{Min}}$ in Summer is $28.9^{\circ} \mathrm{C}$} \\
\hline
\end{tabular}

\begin{tabular}{|c|c|c|c|}
\hline \multicolumn{4}{|c|}{ Spring Minimum Temperature $\left(\mathrm{T}_{\mathrm{Min}}\right)$} \\
\hline Classes Color & Class Category & Count & Frequency Percent \\
\hline & 3 & 17498 & $45.91 \%$ \\
\hline & 4 & 20619 & $54.09 \%$ \\
\hline & & Sum $=38117$ & $100 \%$ \\
\hline \multicolumn{4}{|c|}{ Lowest $\mathrm{T}_{\mathrm{Min}}$ in Spring is $10.4{ }^{\circ} \mathrm{C}$} \\
\hline \multicolumn{4}{|c|}{ Highest $\mathrm{T}_{\mathrm{Min}}$ in Spring is $19.9^{\circ} \mathrm{C}$} \\
\hline
\end{tabular}

\begin{tabular}{|c|c|c|c|}
\hline \multicolumn{4}{|c|}{ Autumn Minimum Temperature $\left(\mathbf{T}_{\mathrm{Min}}\right)$} \\
\hline Classes Color & Class Category & Count & Frequency Percent \\
\hline & 3 & 3852 & $10.11 \%$ \\
\hline & 4 & 34265 & $89.89 \%$ \\
\hline & & Sum $=38117$ & $100 \%$ \\
\hline \multicolumn{4}{|c|}{ Lowest $\mathrm{T}_{\mathrm{Min}}$ in Autumn is $12.6^{\circ} \mathrm{C}$} \\
\hline \multicolumn{4}{|c|}{ Highest $\mathrm{T}_{\text {Min }}$ in Autumn is $19.3^{\circ} \mathrm{C}$} \\
\hline
\end{tabular}

\begin{tabular}{|c|c|c|c|c|c|c|}
\hline Classes Color & & & & & & \\
\hline Class Category & 1 & 2 & 3 & 4 & 5 & 6 \\
\hline Temperature in ${ }^{\circ} \mathrm{C}$ & $0-5$ & $5-10$ & $10-15$ & $15-20$ & $20-25$ & $25-30$ \\
\hline
\end{tabular}

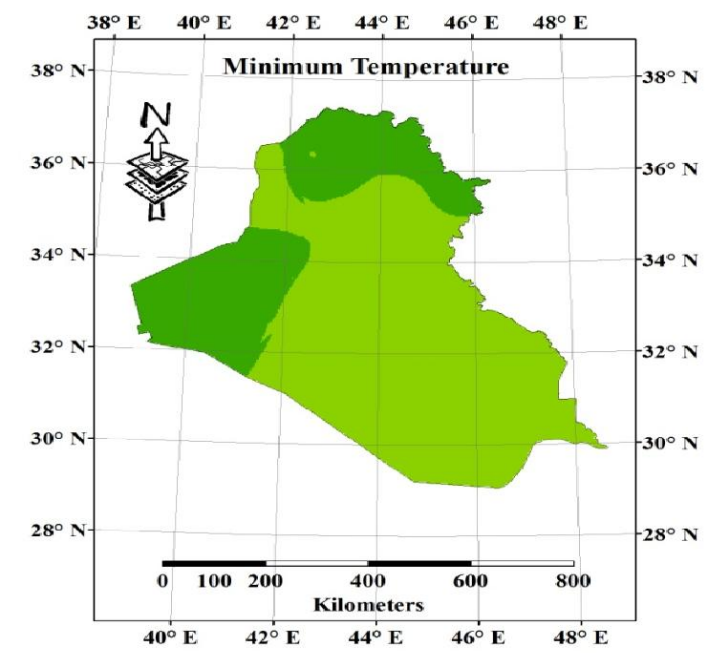

Fig. 7. Spatial Distribution of Annual Minimum temperature in $\left({ }^{\circ} \mathrm{C}\right)$ over Iraq for the period 1980-2015 By Kriging Technique in ArcGis
Table 4. Annual ( $\mathrm{T}_{\min }$ ) over Iraq for the period 1980-2015

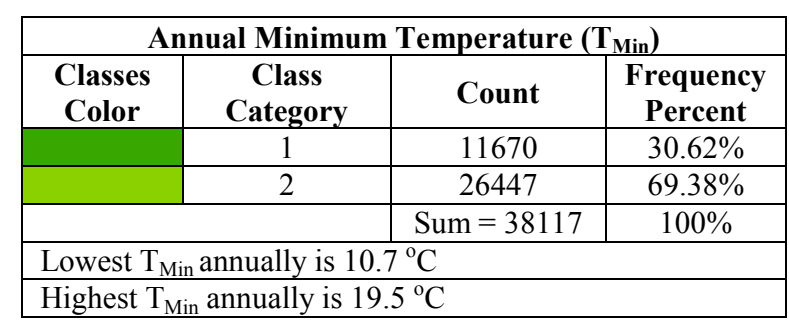

\begin{tabular}{|c|c|c|c|c|c|}
\hline $\begin{array}{c}\text { Classes } \\
\text { Color }\end{array}$ & & & & & \\
\hline $\begin{array}{c}\text { Class } \\
\text { Category }\end{array}$ & 1 & 2 & 3 & 4 & 5 \\
\hline $\begin{array}{c}\text { Temperature } \\
\text { in }{ }^{\circ} \mathrm{C}\end{array}$ & $10-15$ & $15-20$ & $20-25$ & $25-30$ & $30-35$ \\
\hline
\end{tabular}




\section{Conclusion}

This study investigated the seasonal and annual variability on minimum temperature in Iraq. The results show that trends of minimum temperature for annual series, the trends in various regions are increased in northern and southern Iraq. The trend of increasing minimum temperature was about $\left(2.1^{\circ} \mathrm{C} /\right.$ year $)$. In winter season, the increasing trend of minimum temperature was $\left(0.7^{\circ} \mathrm{C} /\right.$ year $)$ in northern of Iraq while it was about $\left(1.75^{\circ} \mathrm{C} /\right.$ year $)$ in southern Iraq. The increasing trend of autumn minimum temperature was the same value in northern and southern parts of Iraq. In spring the rising trend of minimum temperature was $\left(2.45^{\circ} \mathrm{C} /\right.$ year $)$ in the northern and the middle region of the country. The highest value of increasing trend of minimum temperature was in center region of Iraq during the summer with value $\left(3.9^{\circ} \mathrm{C} /\right.$ year $)$.

The results of the spatial analysis of minimum temperature show that the minimum temperature gradient is found to be from the south to the north of Iraq. Seasonally the study area can be divided into two or three distinct areas with high temperature in the south and decreasing toward north.

\section{References}

[1] Jones, P.D., Raper, S.C.B., Bradley, R.S., Diaz, H.F., Kelly, P. M., Wigley, T.M. L., 1986, "A northern hemisphere surface air temperature variations: 1851-1984.," American Meteorological Society, vol. 25, pp. 161-179, February 1986.

[2] Brohan P, Kennedy JJ, Harris I, Tett SFB, Jones PD, "Uncertainty estimates in regional and global observed temperature change: A new data set from 1850," journal of geophysical Research Atmospheres, vol. 111, no. D12106, DOI: 10.1029/2005JD006548., 2006 june 24.

[3] Solomon, S., D. Qin, M. Tignor and H.L. Miller, "Climate Change : The physical Science Basis," Cambridge University Press, Cambridge, United Kingdom, 2007.
[4] Luterbacher. J., D. Diertrich, E. Xoplaki, M. Grosjean and H. Wanne, "European seasonal and annual temperature variability, trends and extremes since 1500," Science, vol. 303, pp. 1499-1503, 2004 March 5.

[5] Pielke, R.A., C.A. Davey, D. Niyogi, S. Fall, J. Steinweg-Woods, K. Gallo, R. hale, R. Mahmood, S. Foster, R.T. McNider and P. Blanken, "Unresolved issues with assessment of multidecadal global and land surface temperature trends," Geophysical Research, vol. 112, no. D24S08, doi: 10 . 1029/2006 JD008229, 2007.

[6] Rabetez, M. and M. Reinhard, "Monthly air temperature trends in Switzerland 19012000 and 1975-2004," Theoretical and Applied Climatology, vol. 91, pp. 27-34, 2007 june 27.

[7] Stafford, J.M., G. Wendler and J.Curtis, "Temperature and precipitation of Alaska:50 year trend analysis," Theoretical and Applied Climatology, vol. 67, pp. 33-44, 2000 March 21.

[8] Miro, J.J., M.J. Esrela and M. Milla'n, "Summer temperature trends in a Mediterranean area (Valancia Region)," contributions to Science, vol. 3, p. 331-342, 2007.

[9] Al Quraishi, Dhiyaa AlDeen Abd Al Hussien Ewaeed (2008). "Thermal properties of the middle and south part of Sedimentary plain in Iraq". MSc. Thesis, College of education Ibn Rushed, Baghdad University.

[10] Soman, M.R., Krishnakumar, K., Singh, N., 1988. Decreassing trend in the rainfall of Kerala. Current science 57, 7-12.

[11] Gilbert, R.O., 1987. "Statistical Methods for environmental pollution monitoring". Van Nostrand Reinhold, New York. 